\title{
Recognizing socioeconomic risks and benefits related to biofuel production in developing countries: framework for analysis
}

\author{
M. Havukainen, S. Väisänen, V. Uusitalo, M. Luoranen, \\ J. Havukainen \& R. Soukka \\ Laboratory of Environmental Technology, \\ Lappeenranta University of Technology, Finland
}

\begin{abstract}
The aim of the paper is to carry out an analysis on socioeconomic risks and benefits of biofuel production on different stages of biofuel production chain. Biofuels have gained increasing attention as an alternative to fossil fuels and as a potential way to reduce the greenhouse gas (GHG) emissions while contributing rural development in developing countries. In this paper socioeconomic risks and benefits related to biofuel production in developing countries were studied by going through related literature. In addition to greenhouse gas emission reductions, biofuel production is also expected to improve rural development. However, according to several studies, they pose some social and economic risks among the local farmers. First of all, the land for biofuel production is often acquired by clearing forest or replacing food production. Second of all, farming may cause some socioeconomic issues if farmers lose the control of their land. On the other hand, sustainable biofuel production could improve rural development and employment in developing countries. The results show that sustainability certificates should be developed further to avoid risks and gain benefits.
\end{abstract}

Keywords: biofuels, socioeconomic risks and benefits, sustainable development, certificates. 


\section{Introduction}

Biofuel production has been growing during the last decade. There are two main reasons for this growth. First of all, biofuels are considered as a clean sources of energy, which are helping Annex 1 countries, as stated by Kyoto protocol, to reach their greenhouse gas (GHG) emission targets. Second of all, there is an increased need for energy and fuel prices are getting higher. In this paper biofuels mean biodiesel and bioethanol produced from crops and oil crops and the studied feedstocks include sugarcane, palm oil and jatropha. The paper aims to summarize the identified socioeconomic risks and benefits of biofuels in developing countries and find out the potential ways to overcome risks and improve the benefits from biofuels. In addition the paper gives an insight to the political forces and agendas that have led to the growth of biofuels.

Many countries have implemented mandatory targets to promote biofuels and governments such as the United States and the European Union have established biofuel mandates to be achieved at target dates. A blend mandate means that a minimum share of biofuel in mixed fuel is required (Harmer [1]) Table 1 presents biofuel mandates of major biofuel consumers.

Policies to promote biofuel production have impact on agricultural commodity production, prices and trade flows. Especially effects of EU biofuel policies are studied. The main effects of EU biofuel policies by 2020 are (Fonseca et al. [2]):

- EU production of biofuels and feedstocks will be higher

- It is uncertain whether the EU's energy independence might be improved by its biofuel policies, particularly when reliance on imported feedstocks is taken into account

- The long-run trend of decreasing agricultural area in EU is slowing down

- World market prices for biofuels will be higher, as a response to increased EU demand for imported biofuel

Table 1: $\quad$ Biofuel mandates by major consumers (Harmer [3]).

\begin{tabular}{|c|c|}
\hline Country & Mandate \\
\hline USA & $\begin{array}{l}\text { Mandatory target of } 7.5 \text { billion gallons of biofuels by 2012, rising } \\
\text { to } 36 \text { billion by } 2022\end{array}$ \\
\hline Brazil & $\begin{array}{l}\text { Mandatory blend of } 20-25 \% \text { anhydrous ethanol with petrol, } \\
\text { mandatory minimum blend of 3\% biodiesel with diesel by July } \\
2008 \text { and } 5 \% \text { by end of } 2010\end{array}$ \\
\hline EU & $\begin{array}{l}\text { Mandatory target of } 10 \% \text { share of renewable (including biofuels) } \\
\text { in transport energy by } 2020\end{array}$ \\
\hline China & $15 \%$ of transport energy needs from biofuels by 2020 \\
\hline Canada & $\begin{array}{l}\text { 5\% renewable content in petrol by 2010; 2\% renewable in diesel } \\
\text { fuel and heating oil by } 2012\end{array}$ \\
\hline India & $\begin{array}{l}\text { Proposed blending mandates of } 5-10 \% \text { of ethanol and } 20 \% \text { of } \\
\text { biodiesel }\end{array}$ \\
\hline
\end{tabular}


Reduction of GHG emission to mitigate climate change is one of the main drivers for biofuel production. Kyoto Protocol has set binding targets for industrialized countries to reduce their GHG emissions. As a result The EU's Renewable Energy Directive RED (2009/28) was created which sets an overall binding target of $20 \%$ for renewable energy in Europe by 2020. Also at least $10 \%$ of each Member State's transport fuel use must come from renewable sources (including biofuels). RED (2009/28) includes criteria for sustainable biofuel production and procedures for verifying that these criteria are met. The criteria are related to GHG savings, land with high biodiversity value, land with high carbon stock and agro-environmental practices. In addition the Commission reports every two years the European Parliament and the Council on the impact on social sustainability in the Community. Also the impact of Community biofuel policy on food security and wider development issues are stated (European Union [4]).

\section{Expectations and concerns related to socioeconomic aspects of biofuels}

The WTO Agreement on Agriculture (AoA) obliged agriculture under a set of international rules in 1995. The agreement required many countries to open agricultural production to international markets and it has been criticized for reducing protections of small farmers in developing countries. According to the WTO's Agriculture Agreement many countries agreed to improve market access and reduce trade-distorting subsidies in agriculture (WTO [5]). However, at the same time developed countries are continuing paying their farmers massive subsidies which developing countries cannot afford (WTO [5]). Even before the massive growth of biofuel production small farmers in developing countries were already struggling to survive.

Land clearing for biofuels production potentially increases deforestation and puts pressure on food prices. The link between biofuel development and deforestation is complicated and very difficult to measure at the global level. Biofuel production potentially causes deforestation both directly and indirectly. However, there is no clear accepted method to assess these indirect effects of biofuels on deforestation (Gao et al. [6]).

If biofuels replace food production, less area is available for food production and the food prices will be increased. According to FAO unavailability of food, insufficient purchasing power, inappropriate distribution, or inadequate use of food at the household level are the main issues endangering food security (FAO [7]). The spike in food prices in 2008 is estimated to have pushed more than 100 million people below the poverty line. However, biofuels could supply 20-30\% of global fuel demand in an environmentally responsible manner without affecting food production (Koonin [8]). Attention to food security has shifted interest toward second-generation that is not based on food crops (Pfuderer et al. [9], Abbot et al. [10], Chen et al. [11]).

Rural development is one of the expectations from biofuels. There is an inevitable link between biofuel production job creation, enhancement of rural 
development and improvement of rural livelihood. In addition rural development is also part of the International Energy Agency (IEA) policy goals. If biofuel productions as well as other agricultural activities are well planned, it could stimulate rural development. However, if biofuel production is not well implemented, it could have adverse impacts on rural development. Appropriate biofuel policies, laws and regulations could enhance the benefits of biofuels (Fargione et al. [12]).

The role of small farmers is extremely vital for rural development. The benefits for small farmers depend on whether they own their own land or simply are forced to sell their village land to investors. In addition rural infrastructure has a key role to play in rural development and improving rural infrastructure will promote biofuel development and agriculture in general. Without appropriate infrastructure biofuel production may not bring any benefits on rural development (Mitchell [13]).

The expanding production of biofuels raised concerns about socioeconomic risks and benefits in developing countries. As a result efforts towards formulation and application of standards and certifications also increased. Roundtable on sustainable palm oil (RSPO) was formed in 2004 and the Roundtable on Sustainable Biofuels (RSB) launched its global certification system to assure the sustainability and traceability of feedstocks and fuels (RSB [14]). International Sustainability and Carbon Certification (ISCC) is another international certification system that can be used to prove sustainability and GHG savings for all kinds of biomass and bioenergy. ISCC has been operating since the beginning of 2010 and is already used by leading companies internationally (ISCC [15]).

\section{Results and discussion}

Based on studies several potential social aspects have been recognised and collected in table 2. Biofuel production comprises of three stages that are land clearing, farming and refining and within each stage different socioeconomic issues take place. In this study we have focused on small farmers and landless people in developing countries. In this paper the most significant potential impacts on small farmers are caused though deforestation, food price increase, livelihood and job creation. The potential socioeconomic risks and benefits of biofuel production are presented in table 2 .

\subsection{Land clearing}

Socioeconomic risks related to land clearing has been a concern all over the developing world. South Korea and China operate in 4.4 million hectares of overseas plantations in Southeast Asia, Africa and Latin America. For example Cambodia and Laos are losing agricultural resources for their richer neighbors such as Thailand and Vietnam. In addition Indonesia and the Philippines lease out large areas to foreign investors, primarily from China and South Korea, with Japan and Malaysia on their heels (Fargione et al. [12]). 
Table 2: $\quad$ Potential socioeconomic issues of biofuel production.

\begin{tabular}{|c|c|c|c|}
\hline Stage & Issues & Description of the issues & Source \\
\hline \multirow[t]{2}{*}{$\begin{array}{l}\text { Land } \\
\text { clearing }\end{array}$} & Deforestation & $\begin{array}{l}\text { The impacts depend on } \\
\text { feedstock used, land available, } \\
\text { the comparative advantages of } \\
\text { biofuel crops versus other } \\
\text { food crops, the technologies } \\
\text { and financial capital and the } \\
\text { existing land } \\
\text { use regulations. }\end{array}$ & $\begin{array}{l}\text { Chen et al. [11] } \\
\text { FAO [16] } \\
\text { Murphy [17] }\end{array}$ \\
\hline & $\begin{array}{l}\text { Food } \\
\text { production } \\
\text { replacement }\end{array}$ & $\begin{array}{l}\text { If food crops are replaced with } \\
\text { energy crops, less area for } \\
\text { food production is available } \\
\text { and food prices will go up. } \\
\text { The food price effects depend } \\
\text { largely on policy design. }\end{array}$ & Braun [18] \\
\hline \multirow[t]{2}{*}{ Farming } & Livelihood & $\begin{array}{l}\text { Livelihood impacts depend } \\
\text { greatly on contracts with } \\
\text { biofuel companies, knowledge } \\
\text { of farmers on biofuel } \\
\text { harvesting, scale of } \\
\text { production, socioeconomic } \\
\text { and policy context of the } \\
\text { country. }\end{array}$ & $\begin{array}{l}\text { Saturnino et al. } \\
{[19]}\end{array}$ \\
\hline & Job creation & $\begin{array}{l}\text { On average biofuel production } \\
\text { requires } 100 \text { more workers per } \\
\text { Joule than fossil fuel industry. } \\
\text { Job effect depends on scale } \\
\text { and mechanization of biofuel } \\
\text { production. }\end{array}$ & $\begin{array}{l}\text { Renner and } \\
\text { McKeown [20] }\end{array}$ \\
\hline
\end{tabular}

Some estimation on deforestation in Malaysia has been done. According to World Bank in Malaysia the area under cereal production has declined from 696,000 hectares in 2003 to 680,000 hectares in 2010. However, the deforestation rate between 2000 and 2010 in Malaysia has been 1.4\%. At the same time the area for palm oil production has grown from 338000 hectares in 2000 to 448,000 hectares in 2008 (World Bank [21]).

The possible deforestation rate caused by biofuel production depends on the area and feedstock. Palm oil plantations are estimated to be one of the main drivers of deforestation in Indonesia while the direct deforestation resulting from sugar-based ethanol in Brazil and Colombia seems to be insignificant. In Brazil the plantations locate approximately 2000 kilometers from Amazon. While in Malaysia, Indonesia are sometimes found in rainforest areas specifically cleared for this purpose, or in areas that had been cleared earlier but planted with rubber 
or coconut (Gao et al. [6]) In addition land is a crucial issue for many indigenous people and others forest dependent people in Indonesia. The Indonesian law does not acknowledge native rights and ownership of lands, as lands are all owned by the government (Friends of the Earth [22]).

Evidence suggests that, at least in Latin America, sugarcane is generally expanding on lands cleared for agriculture a long time ago; it mainly replaced other field crops. Thus, expanded production of ethanol from sugarcane is unlikely to cause direct deforestation, although it may cause indirect land use change by displacing crops or livestock into forests or grasslands (Gao et al. [6]).

In recent years, jatropha has been promoted as a crop that uses 'wastelands', marginal lands or abandoned agricultural lands. However, in practice, dry secondary forests have often been affected, although jatropha's establishment is so recent that it is difficult to find evidence on this feedstock's impact on deforestation (Gao et al. [6]).

Land clearing can also have impact on food security. At the moment only a marginal share of agricultural land is used for biofuel production but the future scenario is not clear. If EU biofuel polices are implemented total land used for cereals, oilseeds and sugar crops worldwide would increase 3.4\% over the period 2008-2020 (Fonseca et al. [2]). At the moment accelerating demand for palm oil is contributing to the $1.5 \%$ annual rate of deforestation of tropical rainforests in Indonesia and Malaysia (Fargione et al. [12]). The role of biofuel policies in the food-price hikes has become particularly controversial. On estimate is that the contribution of the biofuel is $30-75 \%$ of the food price increase in 2008. However, there are large methodological difficulties in measuring the role of biofuel production on food prices (Mitchell [13]).

Before the global food crisis in 2008, an analysis of bioenergy policies showed that despite global reductions in food production, undernourishment may decrease in certain locations, where bioenergy production occurs. It also shows that these income effects can substantially increase agricultural land and food commodity prices while at the same time undernourishment decreases in some locations. However, such effects are not globally valid and are sensitive to policy design (Schneider et al. [23]).

Concerning food security there are number of regional and global initiatives that are currently underway, e.g. the RSB, the RSPO, developing ISO and CEN standards and the existing FSC, PERC and other forestry schemes. The biofuels roles in food security issues were also discussed after the global food crisis in 2008. Despite the recent controversy surrounding the expanding role of biofuels in the transport sector, it is not obvious that the use of food crops for 1st generation biofuels is an automatic cause of conflict. In a best case scenario, energy demand could dispose of unwanted surpluses, keeping crop prices stable and high enough to warrant the investment that has been lacking in the past decades. These schemes are based on rapidly-developing, though presently incomplete, scientific knowledge and modeling tools (Murphy et al. [17]). Also studies indicate that Jatropha can be intercropped with food or use presently unfarmed land unsuitable for other crops. Therefore it is regarded as a potential feedstock to secure food production. However, this would require massive 
improvements of genetic potential of oil yields and the production practices (FAO [24]).

\subsection{Farming}

Impacts of biofuels on job creation have been studied. A study made on liquid biofuel production in 2008 showed how the potential environmental and socioeconomic risks associated with large-scale production of liquid biofuels in developing countries might affect male- and female-headed households differently. This depends on the specific socio-economic and policy context. In some cases liquid biofuels production might even complicate such inequalities, contributing to the socio-economic marginalization of women and female-headed households and threatening their livelihoods, with negative implications in particular for their food security. Men and women might also have different employment opportunities and conditions on plantations of biofuel feedstocks, and might therefore be exposed to different work-related health risks (Rossi and Lambrou [25]).

An outgrower approach might be beneficial for small farmers in developing countries. A case study from Mozambique biofuel sector (2009) covering sugarcane and jatropha concluded that to producing biofuels is more beneficial for small farmers compared with the more capital-intensive plantation approach. The outgrower approach means that the farmer agrees to provide established quantities of a specific agricultural product and in turn, the buyer commits to purchase the product, often at a pre-determined price. In addition the expected benefits of outgrower schemes will be further enhanced if they result in technology spillovers to other crops. However, while welfare and food security broadly increased due to enhanced purchasing power, certain households may be adversely affected due to the price and quantity adjustments associated with rapid growth in biofuel production (Channing et al. [26]). Studies have shown that projects based integration of local communities through outgrower schemes have the potential to contribute to socioeconomic development in African countries by offering additional income opportunities for the rural population (Janssen et al. [27]).

Jatropha is a marginal feedstock in biofuels but it has gained interest especially in South Asia. A case in India showed that after a while a large share of Jatropha plantations were discontinued due to perceived poor performance. Problems arose from limited knowledge about jatropha cultivation, poor planning and implementation of the national jatropha program (Axelsson et al. [28]).

Biofuels production can have impact on job creation since biofuel production requires 100 times more workers per joule of energy content produced than the highly capital-intensive fossil fuel industry (Renner and McKeown [20]). A study made in 2010 Asia-Pacific area concluded that biofuels can create jobs in rural areas through new biorefineries and new feedstock harvesting, seeding, and transportation activities. In addition it is believed that biofuels also provide a logical growth path into increased mechanization. However, one of the issues recognized was that women face some barriers to be engaged in the biofuels 
sector. However, it is believed that women are able to increase gradually their participation in the sector (APEC [29]).

\section{Policy implications}

Biofuels certificates are developed to assure sustainability of biofuel production. For instance RSPO is a global, multi-stakeholder initiative on sustainable palm oil (RSB [14]). With expansion of biofuel productions number of certificates also increased. Large number of certification systems is hard to manage and some experts argue that an increasing number of certification initiatives would just lead to beneficial competition, resulting in constant improvement in standards and standard application. Others point out that further proliferation of standards will lead to a substantial confusion among various stakeholders (Lebandowski and Faaij [30]). According to studies biofuel policies should concentrate on market development and promote sustainable international biofuel trade. Free trade of biofuels should be linked with social and environmental standards and verification systems (World Energy Council [31]).

Certification systems are going to develop in the future. There has been a suggestion of universal standard since there are many similarities and synergies among the different existing schemes. They could be integrated into a single system, thereby reducing the complexity of the current approach. However, it has to be borne in mind that standards are only a single tool to deal with socioeconomic risks and benefits of biofuels (Kaphengst et al. [32]). Independent sustainable palm oil certification can be a useful approach to promote sustainable palm oil production. However, RSPO certification scheme are likely to be above the capacity of most smallholders (World Bank [21]).

However, in the future it is expected that number of areas and countries producing biofuels will also increase, which is making creation of universal sustainability standard more important but also more challenging. In addition number of feedstocks will also increase and possibly bring new socioeconomic risks and benefits that are not yet recognized.

To deal with social concern some investors and companies have adopted a special strategy. One example is The International Finance Corp (IFC), the World Bank's private sector lender, stated in 2009 that it had suspended new investments in palm oil businesses. IFC carried out a study on palm oil plantations and found that did not have adequate approach to social concerns within Indonesian palm oil sector (Reuters [33]). The specific complaints included [34]: illegal use of fire to clear lands, clearance of areas of high conservation value, seizing of indigenous peoples' lands without due process, failure to carry out free, prior, and informed consultations with indigenous peoples leading to broad community support, failure to establish agreed areas of smallholdings, social conflicts that triggered repressive actions by companies and security forces, failure to carry out or wait for approval of legally required environmental risks and benefits assessments.

After all the problems related to palm oil production were recognized World Bank lifted suspension in 2011 and IFC created a new strategy for sustainable 
palm oil based on meeting with 3,000 stakeholders. IFC stated that palm oil investments have potential to economic growth and reduce poverty, while also being environmentally friendly (Reuters [35]). At the moment biofuel feedstocks in general share only a marginal portion of all the agricultural production

As IFC is a relatively small provider of finance and advice within the sector and therefore IFC aims to concentrate on (WTO [5]) investing in relatively underdeveloped areas, such as in poorer countries or frontier regions, where projects will have a relatively larger positive impact (e.g., through direct employment or by supporting smallholders) and where access to capital is constrained; (RSB [14]) engaging selectively with key private sector partners throughout the industry's supply chain (producers, traders, and processors) who are able to demonstrate best practice in environment and social sustainability and community and smallholder engagement; (Renner and McKeown [20]) working with multi-stakeholder initiatives to develop voluntary industry-wide standards for sustainable development (World Bank [36]).

\section{Conclusions}

Rural development was recognized as the main socioeconomic benefit if job creation and technology transfer expectations are met. The most significant risks recognized are related to deforestation and food security. Certificates are one of the most important tools recognized to overcome socioeconomic risks and enhance the benefits. Due to mandates and biofuel policies biofuel production is increasing and therefore socioeconomic issues related to biofuels will become more significant in the future. Some of the risks and benefits that still are in the local level have potential to expand to global level in the future if they are not considered by decision makers, authorities and biofuel producers. To date many of the issues are not yet completely measured and certificates are based on inadequate knowledge. Certificates should be developed further to secure the sustainable biofuel production. Also biofuel schemes should be planned and implemented better and also ensured that the farmers have enough knowledge to harvest feedstocks.

\section{References}

[1] T. Harmer, "Biofuels subsidies and the law of the World Trade Organization," 2009.

[2] M. B. Fonseca, A. Burrell, S. Hubertus, M. Henseler, K. Aikaterini, R. M'Barek, I. Dominguez ja A. Tonini, "Impacts of the EU Biofuel Target on Agricultural Markets and Land Use," Joint research centre, Institute for Prospective Technological Studies, 2010.

[3] T. Harmer, "Biofuels subsidies and the law of the WTO, ICTSD Global Platform on Climate Change," Trade policies and sustainable energy, 2009.

[4] European Union, "Directive 2009/28/EC on the promotion of the use of energy from renewable sources,” European Union, 2009. 
[5] WTO, "World Trade Organisation," 77 2011. [Online]. Available: http://www.wto.org/english/docs_e/legal_e/14-ag_01_e.htm. [Haettu 161 2013].

[6] Y. Gao, M. Skutsch, O. Masera ja P. Pacheco, “A global analysis of deforestation due to biofuel development," Center for International Forestry Research, 2011.

[7] FAO, "State of food insecurity in the World," FAO, 2012.

[8] S. E. Koonin, "Getting serious about biofuels,” 2006.

[9] S. Pfuderer, G. Davies ja I. Mithcell, "The role of demand for biofuel in the agricultural commodity price spikes of 2007/08," Food and Farming Analysis, 2010.

[10] P. C. Abbott, C. Hurt and W. E. Tyner, "What's driving food prices?” Farm foundation, 2008.

[11] X. Chen, H. Haixiao, M. Khanna and H. Önal, "Meeting the Mandate for Biofuels: Implications for Land Use, Food, and Fuel Prices,” 2012.

[12] J. Fargione, J. Hill, D. Tilman, S. Polansky and P. Hawthorne, "Land Clearing and the Biofuel Carbon Debt," Science, 2007.

[13] D. Mitchell, "Note on rising food prices," World Bank Policy Research Working Paper, 2008.

[14] Roundtable for sustainable biofuels, "Roundtable for sustainable biofuels," [Online]. Available: http://rsb.org/. [Haettu 171 2013].

[15] International sustainability and carbon certification, "International sustainability and carbon certification,” [Online]. Available: http://www. iscc-system.org/. [Haettu 112 2013].

[16] Food and Agriculture Organization of the United Nations, "Global forest resource assessment," Food and Agriculture Organization of the United Nations, 2005.

[17] R. Murphy, J. Woods, M. Black and M. McManus, "Global developments in the competition for land from biofuels,” Food policy, pp. 52-61, 2011.

[18] J. Braun, "Impact of Climate Change on food security in times of high food and energy prices," Land management 2, 2008.

[19] M. Saturnino, J. Borras, P. McMichael and I. Scoones, "The politics of biofuels, land and agrarian change: editors’ introduction,” 2010.

[20] M. Renner and A. McKeown, "Promise and pittfalls of biofuels jobs," Biofuels, pp. 7-9, 2010.

[21] World Bank, “The world bank,” [Online]. Available: http://data.worldbank. org/. [Haettu 112 2013].

[22] Friends of the Earth, "Losing Ground The human rights impacts of oil palm plantation expansion in Indonesia," Friends of the Earth, 2008.

[23] U. A. Schneider, C. Llull and P. Havlik, "Bioenergy and Food Security Modeling Income Effects in a Partial Equilibrium Model,” 12th Congress of the European Association of Agricultural Economists, 2008.

[24] Food and Agriculture Organisation of the United Nations (FAO) and Policy Innovation Systems for Clean Energy Security (PISCES), "Small-Scale Bioenergy Initiatives:Brief description and preliminary lessons on 
livelihood impacts from case studies in Asia, Latin America and Africa," PISCES and FAO, 2009.

[25] A. Rossi and Y. Lambrou, "Gender and equity issues in liquid biofuels production minimizing the risks to maximize the opportunities," FAO, 2008.

[26] A. Channing, R. Benfica, F. Tarp, T. James and U. Rafael, "Biofuels, Poverty and Growth A computable general equilibrium analysis of Mozambique," Environment and Development Economics, 2009.

[27] R. Janssen, D. Rutz, P. Helm, J. Woods and R. Diaz-Chavez, "Bioenergy for sustainable development in Africa: Environmental and social aspects," 2010.

[28] L. Axelsson, M. Franzén, M. Ostwald, G. Berndes, G. Lakshmi and N. Ravindranath, "Jatropha cultivation in southern India: assessing farmers' experiences," Biofuels, Bioproducts and Biorefining, 2012.

[29] APEC Energy Working Group, "A Study of Employment Opportunities from Biofuel Production in APEC Economies," APEC Energy Working Group, 2010.

[30] I. Lewandowski and A. Faaij, "Steps towards the development of a certification system for sustainable bio-energy trade," Biomass and Bioenergy, p. 83-104, 2006.

[31] World Energy Council, "Biofuels: Policies,standards and technologies," World Energy Council, 2010.

[32] T. Kaphengst, M. Mandy and S. Schlegel, "At a tipping point? How the debate on biofuel standards sparks innovative ideas for the general future of standardisation and certification schemes," Journal of Cleaner Production, 2009.

[33] Reuters, "Reuters,” [Online]. Available: http://www.reuters.com/article/ 2009/09/09/us-worldbank-palmoil-idUSTRE5886OD20090909. [Haettu 11 2 2013].

[34] International Finance Corporation (IFC), "Audit report: CAO Audit of IFC's investments," 2009.

[35] Reuters, "Reuters," [Online]. Available: http://www.reuters.com/article/ 2011/04/01/worldbank-palmoil-idUSN011595420110401.

[36] World Bank, "The World Bank Group Framework and IFC Strategy for Engagement in the Palm Oil Sector," 2011.

[37] International land coalition, "Meals per gallon. The impact of industrial biofuels on people and global hunger," Action Aid, 22010.

[38] S. Pradhan, "Biofuels and Its Implications on Food Security, Climate Change, and Energy Security:A Case Study of Nepal," Tufts University, 2009.

[39] T. Rice, "Meals per gallon, The impact of industrial biofuels on people and global hunger," ActionAid, 2010.

[40] C. Schott, "Socio-economic dynamics of biofuel development in Asia Pacific,” 2009. 
[41] B. Richardson, J. Anderson, H. Heath, I. Mostad and V. Sivalingam, "Sugarcane and the global land grab:A primer for producers and buyers," 2012.

[42] K. Hermele, "Regulating Sugarcane Cultivation in Brazil," Lund University, 2011.

[43] S. Wiggins, "Institute of development studies," 2110 2009. [Online]. Available: http://www.ids.ac.uk/news/do-small-scale-farms-in-africa-havea-future.

[44] A. Mabiso and D. Weatherspoon, "The Impact of Biofuels Crop and Land Rental Markets on Farm Household Incomes: Evidence from South Africa," 2011.

[45] Malesyan Palm oil board, "Official Portal of Malesyan Palm oil board," [Online]. Available: http://www.mpob.gov.my. [Haettu 112 2013].

[46] House of commons, Environmental audit committee, "Are biofuels sustainable," the House of Commons, 2008.

[47] J. S. E. W. R. M. H. Sanders, "Bio-refinery as the bio-inspired process to bulk chemicals,” Macromolecular Bioscience, pp. 105-117, 2007. 